5

\title{
Chemistry and petrology of paired feed coal and combustion ash from anthracite-burning stoker boilers
}

James C. Hower ${ }^{1}$, Madison M. Hood ${ }^{1}$, Ross K. Taggart ${ }^{2}$, Heileen Hsu-Kim ${ }^{2}$

(1)

${ }^{1}$ University of Kentucky, Center for Applied Energy Research, 2540 Research Park Drive, Lexington, KY 40511 (corresponding author: Hower: 1-859-257-0261, james.hower@uky.edu; Hood: madison.hood@uky.edu )

${ }^{2}$ Duke University, Department of Civil \& Environmental Engineering, Durham, NC 27708 (Taggart: ross.taggart@duke.edu; Hsu-Kim: hsukim@duke.edu )

Abstract

16

The feed coal and corresponding ash from a series of stoker boilers burning Pennsylvania anthracite were investigated for their petrographic and chemical characteristics. The coals have low-S and moderate-ash contents with similar major oxide and minor element compositions. The volatile minor elements, such as $\mathrm{Zn}$ and As, decrease in concentration from the feed coal to the stoker ash (comparisons on the ash basis). The light rare earth elements (La through Sm) decrease in concentration relative to the heavy rare earth elements $(\mathrm{Eu}$ through $\mathrm{Lu})$ from the coal ash to the stoker ash.

Keywords: rare earth elements; arsenic; unburned coal 
41 petrology.

1. Introduction

While there is a great deal of knowledge concerning chemical, mineral, and petrographic transitions from low rank and bituminous coals to solid combustion products, anthracites have not been the subject of nearly as many studies. Suárez-Ruiz et al. (1), Ribeiro et al. (2-3), and Silva et al. (4) investigated the fly ash from pulverizedfuel combustion of Spanish, Portuguese, and Chinese anthracites, respectively.

Investigations of the behavior of anthracite in fluidized bed combustion (FBC) are more common, as in Duan et al.'s (5) study of minor element partitioning in circulating FBC (CFBC) combustion of anthracite and of bituminous coal. Pennsylvania anthracite is generally used for home heating, in industrial and institutional boilers, and for specialty uses, such as for coal-fired pizza ovens. Utility usage of anthracite has, in recent years, largely been confined to CFBC boilers burning the culm (coal plus rock) from pre-reclamation-law mining and beneficiation. The use of limestone in the CFBC process complicates interpretations of the transition from the coal petrology and coal mineralogy and chemistry to the combustion ash chemistry and In this study, the ash from the combustion of known feed coals in several stoker 43 boilers was investigated. The stoker ash generally resembles a bottom ash, with some 44 slag-like fragments, from a pulverized coal boiler. No culm was part of the fuel, 45 meaning that no extraneous rock other than mineral matter included with the 
46 beneficiated coal was included in the stoker feed. Therefore, this investigation provides

47 the opportunity to study the products of anthracite combustion without the interference

48 of CFBC-produced sulfates. Nevertheless, the study is limited in the comparisons to

49 bituminous coal combustion since most of the latter have dealt with the bottom ash and

50 fly ash from pulverized-fuel combustion.

51

52 2. Methods

Feed coal and stoker ash were collected on five days at five different industrial

54 stoker boilers in Pennsylvania's Eastern Middle Anthracite Field (Table 1). In all cases,

55 the feed coal was sampled in the morning and the stoker ash was sampled in the

56 afternoon in an attempt to ensure, given the time lag between combustion and the

57 passage of the ash to the sampling point, that the stoker ash was reasonably

58 representative of the feed coal. Samples were crushed to ca. 6-mm top size. A fraction

59 of the coal and stoker ash from each day were split off to build a composite sample.

60 Representative splits of each of the samples were crushed to -20 mesh $(840 \mu \mathrm{m})$ for

61 petrology and to -60 mesh $(250 \mu \mathrm{m})$ for chemistry.

62 Proximate and ultimate analyses, sulfur forms, and heating value were

63 conducted at the University of Kentucky Center for Applied Energy Research (CAER)

64 following ASTM D7582 15, ASTM D3176 15, ASTM D2492-02(2012), and ASTM D5865

65 13, respectively. Major oxides and minor elements concentrations were quantified by X- 
66

67

68

69

70

71

72

73

74

75

76

77

78

79

80

81

82

83 85

84 and low sulfur content (Table 2). The major oxide and minor element content is

ray fluorescence $(\mathrm{XRF})$ at the CAER following procedures outlined by Hower and Bland

(6). The rare earth elements + yttrium (REY) were extracted from the high-temperature $\left(750^{\circ} \mathrm{C}\right)$ ash samples (as prepared for the XRF analyses) by heated digestion with a 1:1 $\mathrm{HF}: \mathrm{HNO}_{3}$ acid mixture followed by analysis by inductively couple plasma atomic absorption spectroscopy at the CAER (based on published procedures (7)).

Both coal petrology and stoker ash petrology were performed on epoxy-bound pellets prepared to a final $0.05-\mu \mathrm{m}$-alumina polish. The petrographic studies used $50 \mathrm{x}$, reflected-light, oil-immersion optics on Leitz Orthoplan microscopes at the CAER.

Vitrinite reflectance was measured with the incoming light polarized at $45^{\circ}$ and the reflected light passing through a 546-nm bandwidth filter on the path to the photomultiplier. The photomultiplier was standardized using glass standards of known reflectance. Vitrinite reflectance procedures followed ASTM D2798-11a. The maceral analysis followed nomenclature outlined by the ICCP (8-9). The ash petrology followed procedures described by Hower (10).

3. Results and discussion

3.1 Coal and ash chemistry

3 The feed coal has moderate ash yield content (about 8-12\%, as-received basis)

85 relatively consistent between the samples. The total REY (rare earth elements [REE] + 
86 Y) content, 595-695 ppm (ash basis), is within the range of other Appalachian coals (11-

87 12) and similar to the values found in sized coals from anthracite breakers (preparation

88 plants) (13). In addition to the standard REE values, the rare earth element

89 concentrations normalized for the values in the Upper Continental Crust are included

90 (14). The formulas for the normalized $\mathrm{Eu}, \mathrm{Ce}$, and $\mathrm{Gd}$ (15-16), below, are used to

91 decouple the respective elements from the other normalized REE in the distribution

92 patterns:

93

$$
\mathrm{Eu}_{N} / \mathrm{Eu}_{N}{ }^{*}=\mathrm{Eu}_{N} /\left(0.67 \mathrm{Sm}_{N}+0.33 \mathrm{~Tb}_{N}\right)
$$

94

$\mathrm{Ce}_{N} / \mathrm{Ce}_{N}{ }^{*}=\mathrm{Ce}_{N} /\left(0.5 \mathrm{La}_{N}+0.5 \operatorname{Pr}_{N}\right)$

95

$$
\mathrm{Gd}_{N} / \mathrm{Gd}_{N}{ }^{*}=\mathrm{Gd}_{N} /\left(0.33 \mathrm{Sm}_{N}+0.67 \mathrm{~Tb}_{N}\right)
$$

The stoker ash shows the expected loss of volatile elements from the ash-basis

97 coal to the ash. This is evident in the drop in $\mathrm{SO}_{3}$ among the major oxides, but also in

98 the decrease in concentration of $\mathrm{As}$ and $\mathrm{Zn}$, and, to a lesser extent, $\mathrm{Cu}$ and $\mathrm{Pb}$, from the

99 feed coal to the ash. The REY in the coal and stoker ash are similar in concentration to

100 the levels found in many Central Appalachian coals (11-12). The REY show a slight

101 increase in concentration (ash basis) from the coal to the stoker ash, likely owing to the

102 loss of volatile elements. The light REE elements (La through Sm) decrease in

103 concentration relative to the heavy REE (Eu through $\mathrm{Lu}$ ), as seen in the average coal

104 LREE/HREE of $9.80 \mathrm{vs}$. the stoker ash LREE/HREE of 9.42 with a the increase in LREE of 
105550 ppm (ash basis) in the coal to 603 ppm (ash basis) in the stoker ash being offset by

106 the increase in HREE. The $\mathrm{Ce}_{N} / \mathrm{Ce}_{N}^{*}$ decreases (3.68 to 3.48) while the $\mathrm{Gd}_{N} / \mathrm{Gd}_{N}^{*}$ (1.95 to

107 2.10) increases from the coal to the stoker ash, also indicative of the shift in LREE and

108 HREE distributions between the coal and the stoker ash. Heavy REE tend to have an

109 affiliation with the organic structure of coal, at least in low-rank coals (17-24). If this

110 association is retained at the anthracite rank, as chelated elements and/or, probably

111 more likely, as fine minerals formed from elements previously in chelate association at a

112 lower coal rank, it could contribute to the differences in behavior of the subsets of the

113 REE suite. It is certainly possible that more complete combustion of the feed coal and a

114 more complete vitrification of the aluminosilicate minerals would have led to a different

115 distribution of the REE in the stoker ashes.

$117 \quad 3.2$ Coal petrology

118 The coals are dominated by vitrinite group macerals, mainly telovitrinite, with

119 lesser amounts of fusinite and other inertinite macerals (Table 3). Liptinite group

120 macerals are likely to be present, sporinite was noted in sample 94008 and liptinites

121 have been observed in other Pennsylvania anthracites (13), but the convergence of

122 vitrinite and liptinite reflectances makes liptinite detection difficult.

123

Anthracite is a metamorphic rock. While some minerals, quartz, for example,

124 will persist across the rank range, the clays of the bituminous precursors to the 
125 anthracite were transformed to other minerals by the metamorphism of the coal. This

126 will be discussed further in section 3.3. Despite the metamorphism of some clay

127 minerals to micas and other phyllosilicates, for convenience, we will refer to all

128 aluminosilicates observed in the coal by optical petrology as "clay". The mineral

129 assemblages are dominated by clays (Figure 1A) with lesser amounts of siderite (Figure

130 1B-C), pyrite (Figure 1C), and sphalerite (Figure 1D). Further investigation of anthracite

131 petrology, some of it from coals similar to the ones studied here, can be found in Hower

132 and Dai (13).

133 Coal rank within the Pennsylvania anthracite coalfields increases from west to

134 east (25-26). As such, the higher vitrinite maximum reflectance feed coals, samples

13593998 and 94000, have a greater proportion of the feedstock from the easternmost mines

136 in the Eastern Middle Anthracite Field.

137

$138 \quad 3.3$ Stoker ash petrology

139 The stoker ash petrology is dominated by glass with significant amounts of

140 unburned or partially burned coal and lesser amounts of rock fragments, mullite,

141 spinel, sulfate and/or other oxidized minerals, and other less common mineral and

142 carbon forms (Table 4).

143

Anthracite, particularly anthracite approaching meta-anthracite rank as with the

144 feed coals in this study, is not going to melt and repolymerize, as would be the case 
145 with the Appalachian-sourced bituminous caking coals commonly used in eastern US

146 power plants. In the pulverized-fuel combustion of anthracites, the carbons can appear

147 as intact or charred particles $(1,4)$. Some of the coal in the stoker ash appears to have

148 been unburned (Figure 2A-B). Considering that the coal was crushed to obtain the size

149 preferred for petrology, such observations may actually be of the unburned interiors of

150 much larger particles. More common are occurrences such as seen in Figures 2C-D

151 where the effects of heating are visible as eroded and darker edges and voids within the

152 coal particles. Along with the unburned coal, rock fragments are a sign of less efficient

153 heating (and combustion) associated with the stokers. The rock fragments (Figure 3)

154 show a baked, but not vitrified, interior with a vitrified, glassy rim.

155 Spinel minerals (Figure 4), including magnetite along with a number of other Ni-,

$156 \mathrm{Cr}-$, Al- bearing and other spinel varieties, represent the thermal degradation of sulfides

157 and other Fe-bearing minerals in the feed coal. The minerals can occur in coarse to sub-

158 micron sizes, usually in a glassy matrix. Some of this complexity is seen in Figure 4A-C,

159 all of which seem to represent welded particles (in particular, Figure 4C) with some

160 growth of larger crystals between spinel-bearing spheres (Figure 4A). Dendritic

161 development of the minerals is seen in Figures 4A (upper left), 4B (left center), and 4C.

162 Figure 4D is an example of the coarse, complex grains observed in these ashes and in fly

163 ashes and bottom ashes from pulverized-fuel combustion. The red oxidation rims

164 surrounding the welded spheres in Figure $4 \mathrm{C}$ and on the left side of the Figure 4D 
165 particle are common features on many spinel and glass grains in these stoker ashes and 166 in the broader universe of fly ash and bottom ash.

167 As noted, glass, with and without fine mineral inclusions, is the most abundant 168 constituent of the stoker ash. Since the glass is also representative of the most abundant 169 minerals in the feed coal, it is worth noting that the mineralogy of an anthracite and the 170 bounding and interburden rocks is not necessarily the same as in a bituminous or lower 171 rank coal. Shale mineral assemblages in the Anthracite Fields are dominated by K- and $172 \mathrm{NH}_{4}$-illites, kaolinite, pyrophyllite, quartz, and Fe-rich chlorite with mixed-layer 173 chlorite/smectite and illite/smectite with minor to trace amounts of Na-rich illite 174 (brammallite) and paragonite (27-32). With an increase in rank, and our coals are at the 175 high end of the regional rank series, kaolinite contents decrease and illite and 176 pyrophyllite contents increase. The mineral transformations have an impact on the 177 melting behavior of the rock fragments in the boiler with kaolinite, melting in the 450$178700^{\circ} \mathrm{C}$ range (33-34), being replaced by assemblages of illite $\left(>1400^{\circ} \mathrm{C}\right.$ melting $\mathrm{T}$, 179 depending on the chemical composition (35)), mullite (stable high-T mineral forming at $180980^{\circ} \mathrm{C}$ in transformation from metakaolinite (36)), pyrophyllite, and paragonite. Studies 181 of metamorphic rocks show that pyrophyllite transitions to cristobalite and mullite at $1821200^{\circ} \mathrm{C}(37)$ and paragonite transitions to albite and andalusite at about $500^{\circ} \mathrm{C}$ and to 183 sillimanite at about $840^{\circ} \mathrm{C}(38)$. 
As a short step beyond the rock fragments discussed above, Figure 5A shows a glass fragment with an internal structure reminiscent of shale. Figure 5B shows a variety of glass forms, from glass with included minerals (upper left) to glass with no 187 apparent inclusions (diagonal from upper right to center) to glass with Fe-oxides. The 188 inclusion of Fe-oxides in glass is also seen in Figure 5C and in the rim surrounding the 189 glass + minerals sphere in Figure 5D. Transitions in the density of mineral inclusions 190 are seen in Figure 5E. In this case, the glass + bladed mineral assemblage of the left half 191 of the image gives way to a denser packing of mineral in the right third of the image. A $1925-10-\mu \mathrm{m}$ rim seems to have either no inclusions or, more likely, much finer inclusions 193 than the mineral-rich assemblage to its left. The structure of the rim is likely a function 194 of the more-rapid cooling of the rim versus the interior of the particle. The structure of 195 the interior is a function of the cooling history and the chemistry of the melted slag. 196 Figure 5F shows glass, possibly with mineral inclusions, with a structure reminiscent of 197 vermicular kaolinite.

\section{Summary}

Combustion ash sourced from known anthracite blends in several stoker boilers was investigated. The feed coals are moderate ash (8-12\%, as-received basis) with low

202 sulfur. The coal petrology is dominated by vitrinite group macerals, primarily

203 telovitrinite, with lesser amounts of fusinite. Clays and their metamorphic products 
204 dominate the minerals in the coal, with lesser amount of pyrite, sphalerite, and siderite.

205 The fly ash petrology is dominated by glass with significant amounts of unburned and 206 partially burned coal. Rock fragments, usually rimmed by glass, are minor constituents 207 in the ash. Sulfur (measured as $\mathrm{S}_{\text {and }} \mathrm{SO}_{3}$ ) decreases from the coal to the ash. Among 208 the minor elements, $\mathrm{As}, \mathrm{Zn}, \mathrm{Cu}$, and $\mathrm{Pb}$ decrease from the coal ash to the stoker ash.

209 Comparing the coal ash versus the stoker ash, the concentration of light REE's decreases 210 relative to the heavy REE's.

211

212 Acknowledgments

We wish to thank Tom Lowe, Boyd Kreglow, and Greg Driscoll (Blaschak Coal)

214 and Harold Schobert (consultant to Blaschak Coal) for their assistance in acquiring 215 samples and for their guidance in the preparation of this manuscript. This work was supported by National Science Foundation grants CBET-1510965

217 and CBET-1510861 to Duke University and the University of Kentucky, respectively, 218 and U.S. Department of Energy - National Energy Technology Laboratory contract DE$219 \quad$ FE0026952. 
References

1. Suárez-Ruiz I, Hower JC, Thomas GA. Hg and Se Capture and Fly Ash Carbons from Combustion of Complex Pulverized Feed Blends Mainly of Anthracitic Coal Rank in Spanish Power Plants. Energy \& Fuels 2007; 21: 59-70.

2. Ribeiro J, DaBoit K, Flores D, Kronbauer MA, Silva LFO. Extensive FE-SEM/EDS, HRTEM/EDS and ToF-SIMS studies of micron- to nano-particles in anthracite fly ash. Science of the Total Environment 2013; 452-453: 98-107.

3. Ribeiro J, Valentim B, Ward C, Flores D. Comprehensive characterization of anthracite fly ash from a thermo-electric power plant and its potential environmental impact. International Journal of Coal Geology 2011; 86: 204-212.

4. Silva LFO, Jasper A, Andrade ML, Sampaio CH, Dai S, Li X, Li T, Chen W, Wang X, Liu H, Zhao L, Hopps SG, Jewell RF, Hower JC. Applied investigation on the interaction of hazardous elements binding on ultrafine and nanoparticles in Chinese anthracite-derived fly ash. The Science of the Total Environment 2012; 419: 250-264.

5. Duan L, Sun H, Jiang Y, Anthony EJ, Zhao C. Partitioning of trace elements, As, Ba, Cd, Cr, $\mathrm{Cu}, \mathrm{Mn}$ and $\mathrm{Pb}$, in a $2.5 \mathrm{MW}$ th pilot-scale circulating fluidised bed combustor burning an anthracite and a bituminous coal. Fuel Processing Technology 2016; 146: 1-8.

6. Hower JC, Bland AE. Geochemistry of the Pond Creek coal bed, Eastern Kentucky coalfield. International Journal of Coal Geology 1989; 11: 205-26.

7. Taggart RK, Hower JC, Dwyer GS, Hsu-Kim H. Trends in the rare-earth element content of U.S.-based coal combustion fly ashes. Environmental Science \& Technology 2016; 50: 5919-5926.

8. International Committee for Coal Petrology (ICCP). The new vitrinite classification (ICCP System 1994). Fuel 1998; 77: 349-358.

9. International Committee for Coal Petrology (ICCP). The new inertinite classification (ICCP System 1994). Fuel 2001; 80: 459-471.

10. Hower JC. Petrographic examination of coal-combustion fly ash. International Journal of Coal Geology 2012; 92: 90-97.

11. Hower JC, Groppo JG, Henke KR, Hood MM, Eble CF, Honaker RQ, Zhang W, Qian D. Notes on the potential for the concentration of rare earth elements and Yttrium in coal combustion fly ash. Minerals 2015; 5: 356-366. 
12. Hower JC, Eble CF, Dai S, Belkin HE. Distribution of rare earth elements in eastern Kentucky coals: Indicators of multiple modes of enrichment? International Journal of Coal Geology 2016; 160-161: 73-81.

13. Hower JC, Dai S. Petrology and Chemistry of sized Pennsylvania anthracite, with emphasis on the distribution of Rare Earth Elements. Fuel 2016; 185: 305-315.

14. Seredin VV, Dai S. Coal deposits as a potential alternative source for lanthanides and yttrium. International Journal of Coal Geology 2012; 94: 67-93.

15. Dai S, Graham IT, Ward CR. A review of anomalous rare earth elements and yttrium in coal. International Journal of Coal Geology 2016; 159: 82-95.

16. Dai S, Xie P, Jia S, Ward CR, Hower JC, Yan X, French D. Enrichment of U-Re-V-Cr-Se and rare earth elements in the Late Permian coals from the Moxinpo Coalfield, Chongqing, China: Genetic implications from geochemical and mineralogical data. Ore Geology Reviews 2017; 80: $1-17$.

17. Eskenazy G. Rare-earth elements in some coal basins of Bulgaria. Geologica Balcanica 1978; 8: 81-88.

18. Eskenazy GM. Rare earth elements and yttrium in lithotypes of Bulgarian coals. Organic Geochemistry 1987; 11: 83-9.

19. Eskenazy GM. Zirconium and hafnium in Bulgarian coals. Fuel 1987; 66: 1652-1657.

20. Eskenazy GM. Rare earth elements in a sampled coal from the Pirin Deposit, Bulgaria. International Journal of Coal Geology 1987; 7: 301-314.

\section{Eskenazy G. Geochemistry of rare earth elements in Bulgarian coals. Annuaire de} l'Universite' de Sofia “St. Kliment Ohridski", Faculte' de Geologie et Geographie. Livre 1Geologie 1995; 88: 39-65.

22. Eskenazy GM. Aspects of the geochemistry of rare earth elements in coal: An experimental approach. International Journal of Coal Geology 1999; 38: 285-95.

23. Eskenazy GM. Sorption of trace elements on xylain: An experimental study. International Journal of Coal Geology 2015; 150-151: 166-169.

24. Eskenazy GM., Mincheva EI, Rousseva DP. Trace elements in lignite lithotypes from the Elhovo coal basin. Comptes rendus del'Académie bulgare des Sciences 1986; 39 (10): 99-101. 
25. Hower JC, Levine JR, Skehan JW SJ, Daniels EJ, Lewis SE, Davis A, Gray RJ, Altaner SP. Appalachian anthracites. Organic Geochemistry 1993; 20: 619-42.

26. Ruppert LF, Hower JH, Levine JR, Ryder RT, Trippi MH, Grady WC. Geologic controls on thermal maturity patterns in Pennsylvanian coal-bearing rocks in the Appalachian basin. International Journal of Coal Geology 2010; 81: 169-81.

27. Hosterman JW, Wood GH Jr, Bergin MJ. Mineralogy of underclays in the Pennsylvania Anthracite region. U.S. Geoligcal Survey Professional Paper 1970; 700-C: 89-98.

28. Paxton ST. Relationships between Pennsylvanian age lithic sandstone and mudrock diagenesis and coal rank in the central Appalachians. Ph.D. dissertation, Pennsylvania State University, University Park, Pa., 1983; 503 p.

29. Juster TC, Brown PE, Bailey SW. NH 4-bearing illite in very low-grade metamorphic rocks associated with coal, northeastern Pennsylvania. American Mineralogist 1987; 72: 555-565.

30. Daniels EJ, Altaner SP. Clay mineral authigenesis in coal and shale from the Anthracite region, Pennsylvania. American Mineralogist 1990; 75: 825-39.

31. Daniels EJ, Altaner SP, Marshak S, Eggleston JR. Hydrothermal alteration in anthracite from eastern Pennsylvania: Implications for mechanisms of anthracite formation. Geology 1990; 18: 247-50.

32. Daniels EJ, Aronson JL, Altaner SP, Clauer N. Late Permian age of $\mathrm{NH}_{4}$-bearing illite in anthracite from eastern Pennsylvania: Temporal limits on coalification in the Central Appalachians. Geological Society of America Bulletin 1994; 106: 760-6.

33. Insley H, Ewell RH. Thermal behavior of the kaolin minerals. Journal of Research of the National Bureau of Standards 1935; 14: 615-627.

34. Endell J. Clay minerals in coals and in their ashes. Clay Minerals 1955; 2: 289-293.

35. Srinivasachar S, Helble JJ, Boni, AA, Shah N, Huffman GP, Huggins FE. Mineral behavior during coal combustion 2. Illite transformations. Progress in Energy and Combustion Science 1990; 16: 293-302.

36. Schieltz NC, Soliman MR. High temperature transformations of kaolinite. Clays and Clay Minerals 1964; 13: 419-428.

37. Hida T, Kitagawa R. Pyrophyllite. In: Kogel, J.E., et al. Industrial Minerals \& Rocks: Commodities, Markets, and Uses ( $7^{\text {th }}$ ed.), Littleton, CO, Society for Mining, Metallurgy, and Exploration 2006; 755-767. 
348

349 38. Chatterjee ND., Froese E. A thermodynamic study of the pseudobinary join muscovite-

350 paragonite in the system $\left.\mathrm{KAlSi}_{3} \mathrm{O}_{8}-\mathrm{Na} \mathrm{AlSi}_{3} \mathrm{O}_{8}-\mathrm{Al}_{2} \mathrm{O}_{3}-\mathrm{SiO}_{2}-\mathrm{H}_{2}\right)$. American Mineralogist 1975; 60:

$351985-993$

352 
$353 \quad$ Figure captions

354

355

1. Minerals in coal.

356 A/ Clay (c) in fusinite lumens. Image 9400601.

357 B/ Siderite (s). Image 9400603.

358 C/ Pyrite (py) in siderite (s). Image 9400805.

359 D/ Sphalerite (arrow). Image 9400804.

360

2. Coal in stoker ash.

362 A/ Vitrinite (v), secretinite (sc), and fusinite/semifusinite (f). Image 9400103.

363 B/ Vitrinite (v), micrinite (mi), and inertodetrinite (id)/ Image 9400304.

$364 \mathrm{C} /$ Vitrinite with indications of heating, as seen in the darker regions along edge of 365 particle. Image 9400311.

366 D/ Vitrinite with indications of heating, as seen in the darker regions along edge of

367 particle and in the center of the image. Image 9400707.

368

369

3. Rock fragments.

370 A/ Rock fragment (r) with glassy rim. Image 9399901.

371 B/ Rock fragment (r) in glass (g). Image 9400112.

372

373 4. Spinel.

374 A/ Spinel in glassy matrix. Image 9400706.

375 B/ Spinel in glassy matrix. Image 9400104.

376 C/ Spinel in glassy matrix; note red oxidation rim around edge of spheres. Image 94003 37702.

378 D/ Spinel in glassy matrix; note red oxidation rim around edge of particle. Image 94001 37916.

380

5. Glass and included minerals.

382 A/ Glass with banding reminiscent of layering of clays in shale. Image 9399906.

383 B/ Three forms of glass: upper left - glass with bladed mineral inclusions; upper right 384 and center across diagonal - glass with no apparent inclusions; and lower left - glass, 385 apparently with oxidized Fe minerals. Image 9400113.

386 C/ Glass, apparently with oxidized Fe minerals. Image 94009002.

387 D/ Glass with bladed crystals and red oxidation rim. Image 9400107.

388 E/ Glass on left with included bladed minerals. Denser packing of minerals in right 389 third of image. Image 94009003.

390 F/ Glass with banding reminiscent of vermicular kaolinite. Image 9400909. 
392 Table captions

393

394 1. Sample numbers for coal and ash along with the stoker type.

395

396 2. Coal and ash chemistry. As-received ash, Moisture, volatile matter, fixed carbon, 397 ultimate analysis (C, H, N, S, O), sulfur forms, heating value (MJ/kg); major oxides (wt. $398 \%$, ash basis); Cl (wt. \%, whole coal); minor elements, Sc, Y, rare earth elements (ppm; 399 ash basis); total rare earths + Y (REY); total rare earths (REE); light REE; heavy REE; 400 ration of LREE to HREE.

401

402 3. Whole-coal and mineral-free maceral and mineral composition (vol. \%) and vitrinite 403 maximum and random reflectances (and standard deviations) for each of the daily coal 404 samples and the composite sample.

405

406 4. Fly ash petrology (vol. \%) for each of the daily ash samples and the composite 407 sample. 

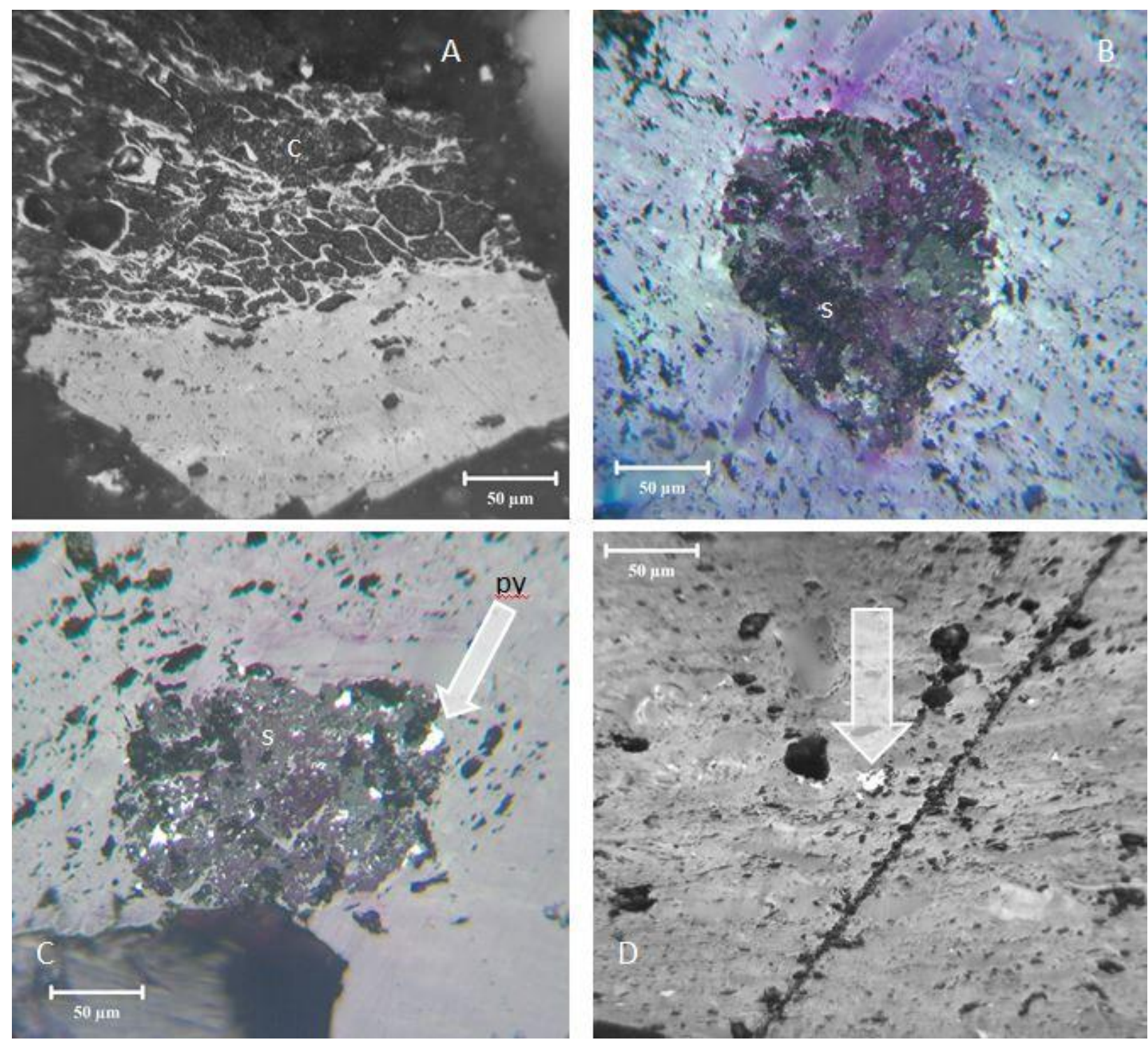

409

410 

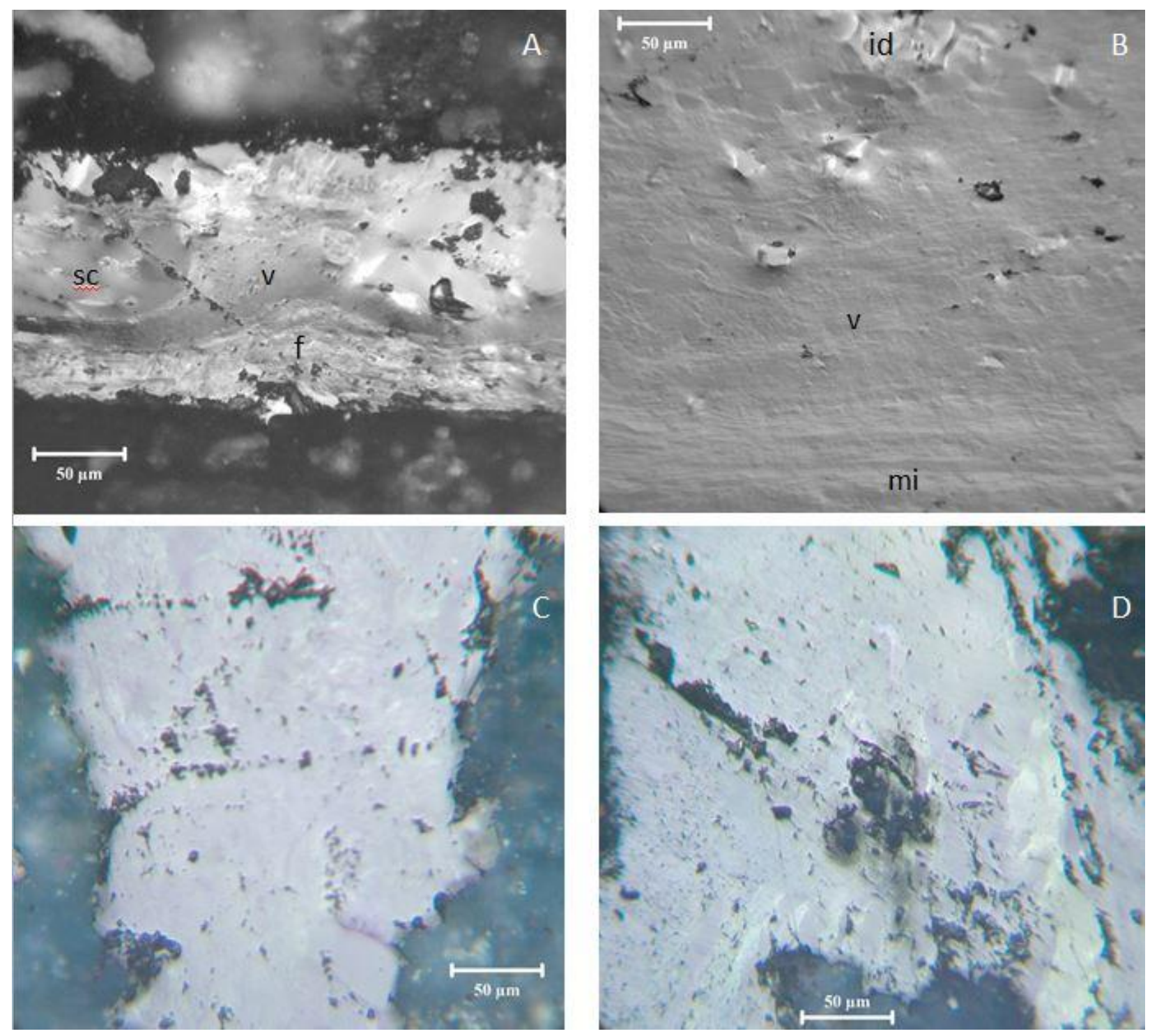

411
412 
413
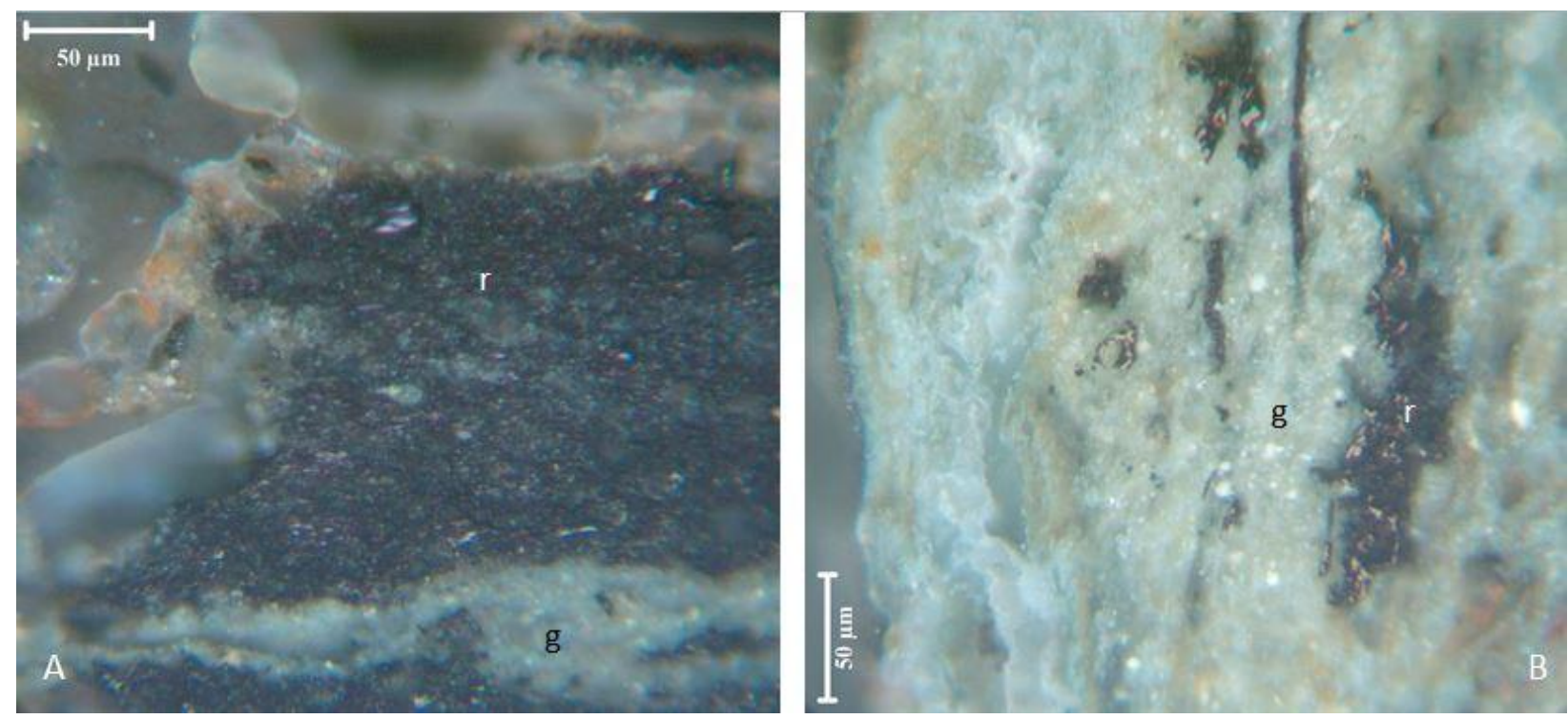

414 

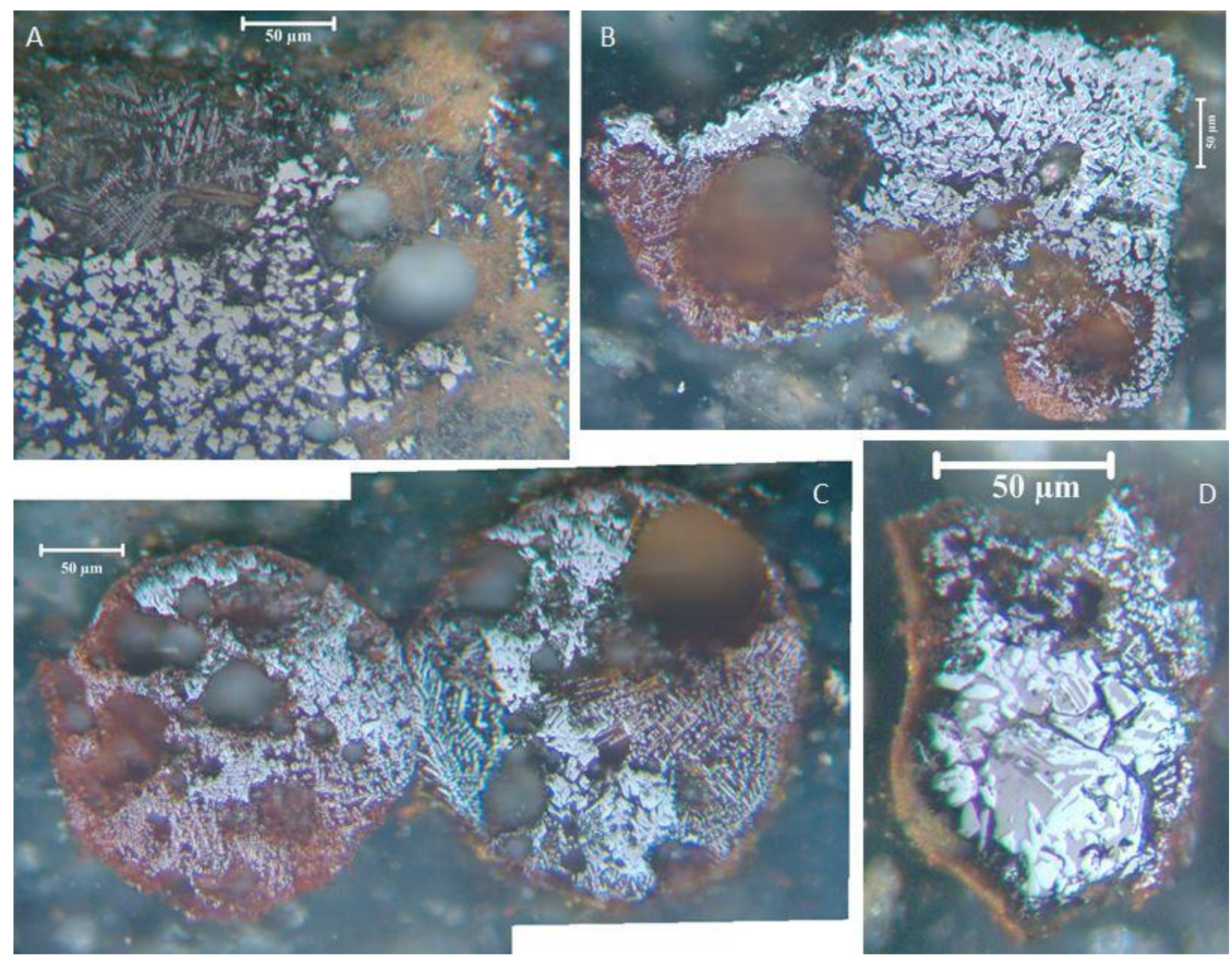

416 

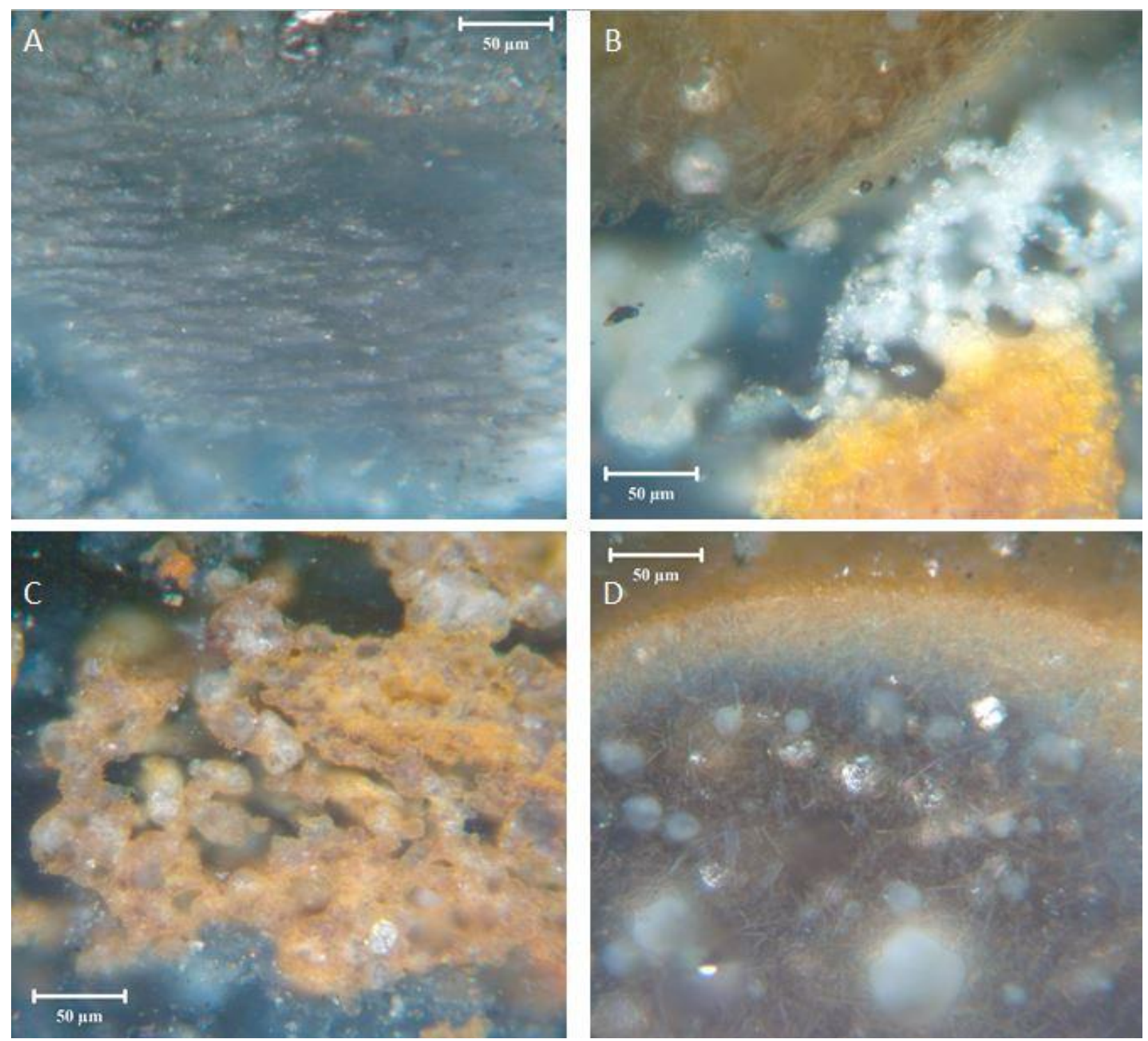

417

418 

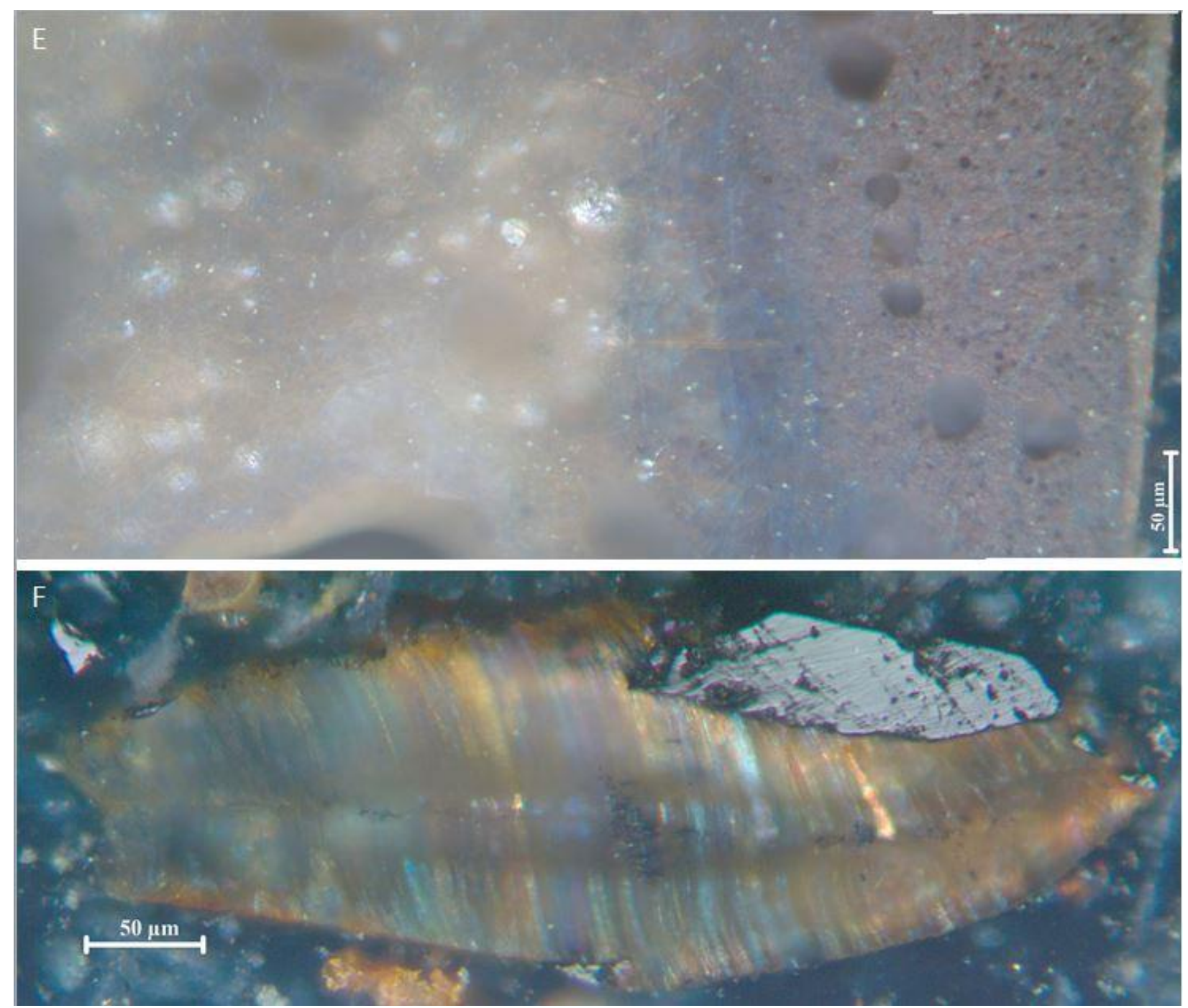


$\begin{array}{ccccc}\text { Key \# } & \text { KCER\# } & \text { MA\# } & \text { Type } & \text { Stoker Type } \\ 1 & 93998 & 75706 & \text { Coal } & \\ 1 & 93999 & 75712 & \text { Ash } & \text { EFM } \\ & & & & \\ 2 & 94000 & 75707 & \text { Coal } & \\ 2 & 94001 & 75713 & \text { Ash } & \text { Baeromatic } \\ & & & & \\ 3 & 94002 & 75708 & \text { Coal } & \\ 3 & 94003 & 75714 & \text { Ash } & \text { Harman } \\ 4 & 94004 & 75709 & \text { Coal } & \\ 4 & 94005 & 75715 & \text { Ash } & \text { Harman DVC 500 } \\ 5 & & & & \\ 5 & 94006 & 75710 & \text { Coal } & \\ 5 & 94007 & 75716 & \text { Ash } & \text { Harman } \\ \text { composite } & 94008 & 75711 & \text { Coal } & \\ \text { composite } & 94009 & 75717 & \text { Ash } & \\ & & & & \end{array}$




\begin{tabular}{|c|c|c|c|c|c|c|c|c|c|c|c|c|c|c|c|}
\hline MANumber & SampleID & material & key & Ash & Mois & $\mathrm{VM}$ & $\mathrm{FC}$ & $\mathrm{C}$ & $\mathrm{H}$ & $\mathrm{N}$ & $\mathrm{S}_{\text {total }}$ & $\mathrm{S}_{\mathrm{py}}$ & $\mathrm{S}_{\text {sulf }}$ & $\mathrm{S}_{\mathrm{org}}$ & $\mathrm{O}$ \\
\hline 75706 & 93988 & coal & 1 & 10.65 & 2.91 & 5.42 & 81.02 & 81.60 & 2.48 & 0.76 & 0.62 & 0.13 & 0.03 & 0.46 & 3.89 \\
\hline 75707 & 94000 & coal & 2 & 8.07 & 5.37 & 5.09 & 81.47 & 79.68 & 2.70 & 0.69 & 0.58 & 0.06 & 0.01 & 0.51 & 8.28 \\
\hline 75708 & 94002 & coal & 3 & 9.94 & 5.57 & 5.50 & 78.99 & 81.52 & 2.55 & 0.71 & 0.63 & 0.12 & 0.02 & 0.49 & 4.65 \\
\hline 75709 & 94004 & coal & 4 & 12.09 & 3.69 & 5.57 & 78.65 & 78.67 & 2.51 & 0.70 & 0.64 & 0.16 & 0.02 & 0.46 & 5.39 \\
\hline 75710 & 94006 & coal & 5 & 9.91 & 5.40 & 5.64 & 79.05 & 79.96 & 2.59 & 0.64 & 0.63 & 0.13 & 0.01 & 0.49 & 6.27 \\
\hline 75711 & 94008 & coal & comp. & 10.14 & 4.68 & 5.36 & 79.82 & 80.16 & 2.53 & 0.65 & 0.67 & 0.13 & 0.01 & 0.53 & 5.85 \\
\hline 75712 & 93999 & ash & 1 & 60.92 & 0.38 & & & 39.39 & 0.52 & 0.09 & 0.17 & & & & $\mathrm{dl}$ \\
\hline 75713 & 94001 & ash & 2 & 60.88 & 4.15 & & & 35.24 & 0.73 & 0.07 & 0.14 & & & & 2.94 \\
\hline 75714 & 94003 & ash & 3 & 59.54 & 0.43 & & & 39.04 & 0.46 & 0.12 & 0.33 & & & & 0.51 \\
\hline 75715 & 94005 & ash & 4 & 59.38 & 0.56 & & & 39.19 & 0.48 & 0.16 & 0.22 & & & & 0.57 \\
\hline 75716 & 94007 & ash & 5 & 64.56 & 0.44 & & & 35.58 & 0.42 & 0.10 & 0.11 & & & & $\mathrm{dl}$ \\
\hline 75717 & 94009 & ash & comp. & 61.38 & 0.86 & & & 36.87 & 0.47 & 0.09 & 0.14 & & & & 1.05 \\
\hline MANumber & SampleID & material & key & $\mathrm{SiO}_{2}$ & $\mathrm{Al}_{2} \mathrm{O}_{3}$ & $\mathrm{Fe}_{2} \mathrm{O}_{3}$ & $\mathrm{CaO}$ & $\mathrm{MgO}$ & $\mathrm{Na}_{2} \mathrm{O}$ & $\mathrm{K}_{2} \mathrm{O}$ & $\mathrm{P}_{2} \mathrm{O}_{5}$ & $\mathrm{TiO}_{2}$ & $\mathrm{SO}_{3}$ & & $\mathrm{Cl}$ \\
\hline 75706 & 93988 & coal & 1 & 51.85 & 33.60 & 8.02 & 0.70 & 0.94 & 0.21 & 2.18 & 0.17 & 2.49 & 0.21 & & 0.16 \\
\hline 75707 & 94000 & coal & 2 & 50.18 & 34.55 & 6.66 & 0.78 & 0.86 & 0.28 & 2.27 & 0.31 & 2.49 & 0.21 & & 0.14 \\
\hline 75708 & 94002 & coal & 3 & 51.20 & 33.68 & 7.21 & 0.63 & 0.90 & 0.25 & 2.36 & 0.21 & 2.51 & 0.19 & & 0.14 \\
\hline 75709 & 94004 & coal & 4 & 51.64 & 32.53 & 7.32 & 0.57 & 0.94 & 0.26 & 2.42 & 0.17 & 2.46 & 0.17 & & 0.15 \\
\hline 75710 & 94006 & coal & 5 & 50.95 & 33.76 & 7.57 & 0.66 & 0.90 & 0.23 & 2.29 & 0.22 & 2.52 & 0.18 & & 0.14 \\
\hline 75711 & 94008 & coal & comp. & 51.45 & 32.86 & 7.04 & 0.64 & 0.87 & 0.24 & 2.27 & 0.21 & 2.47 & 0.22 & & 0.13 \\
\hline 75712 & 93999 & ash & 1 & 50.48 & 33.86 & 7.06 & 0.84 & 0.87 & 0.27 & 2.26 & 0.27 & 2.41 & 0.14 & & \\
\hline 75713 & 94001 & ash & 2 & 51.33 & 33.12 & 7.23 & 0.53 & 0.98 & 0.28 & 2.35 & 0.11 & 2.41 & $\mathrm{dl}$ & & \\
\hline 75714 & 94003 & ash & 3 & 51.22 & 34.19 & 6.79 & 0.75 & 0.90 & 0.24 & 2.19 & 0.27 & 2.53 & $\mathrm{dl}$ & & \\
\hline 75715 & 94005 & ash & 4 & 51.55 & 33.17 & 7.72 & 0.76 & 0.88 & 0.29 & 2.33 & 0.29 & 2.31 & 0.03 & & \\
\hline 75716 & 94007 & ash & 5 & 51.59 & 33.69 & 7.07 & 0.76 & 0.91 & 0.24 & 2.19 & 0.28 & 2.43 & 0.05 & & \\
\hline 75717 & 94009 & ash & comp. & 51.90 & 33.51 & 6.94 & 0.72 & 0.90 & 0.26 & 2.30 & 0.25 & 2.48 & 0.02 & & \\
\hline
\end{tabular}




\begin{tabular}{cccccccccccccccccccc}
\hline MANumber & SampleID & material & key & $\mathrm{V}$ & $\mathrm{Cr}$ & $\mathrm{Mn}$ & $\mathrm{Co}$ & $\mathrm{Ni}$ & $\mathrm{Cu}$ & $\mathrm{Zn}$ & $\mathrm{As}$ & $\mathrm{Rb}$ & $\mathrm{Sr}$ & $\mathrm{Zr}$ & $\mathrm{Mo}$ & $\mathrm{Cd}$ & $\mathrm{Sb}$ & $\mathrm{Ba}$ & $\mathrm{Pb}$ \\
\hline 75706 & 93988 & coal & 1 & 728 & 227 & 415 & 96 & 157 & 205 & 109 & 22 & 371 & 278 & 344 & 167 & $\mathrm{dl}$ & 9 & 1128 & 76 \\
75707 & 94000 & coal & 2 & 765 & 247 & 337 & 86 & 147 & 199 & 121 & 30 & 357 & 487 & 354 & 192 & $\mathrm{dl}$ & 8 & 1281 & 76 \\
75708 & 94002 & coal & 3 & 711 & 227 & 348 & 93 & 159 & 235 & 154 & 28 & 362 & 339 & 337 & 184 & $\mathrm{dl}$ & 9 & 1168 & 77 \\
75709 & 94004 & coal & 4 & 675 & 216 & 405 & 82 & 142 & 194 & 162 & 33 & 344 & 303 & 337 & 181 & $\mathrm{dl}$ & 8 & 1138 & 79 \\
75710 & 94006 & coal & 5 & 723 & 229 & 380 & 101 & 164 & 202 & 119 & 29 & 355 & 371 & 341 & 171 & $\mathrm{dl}$ & 8 & 1184 & 79 \\
75711 & 94008 & coal & comp. & 702 & 226 & 341 & 92 & 151 & 219 & 112 & 28 & 366 & 344 & 342 & 195 & $\mathrm{dl}$ & 8 & 1178 & 75 \\
75712 & 93999 & ash & 1 & 719 & 241 & 330 & 79 & 132 & 131 & 48 & $\mathrm{dl}$ & 490 & 361 & 301 & 118 & $\mathrm{dl}$ & 4 & 1230 & 65 \\
75713 & 94001 & ash & 2 & 652 & 208 & 358 & 81 & 139 & 37 & 34 & $\mathrm{dl}$ & 496 & 173 & 267 & 91 & $\mathrm{dl}$ & 2 & 1146 & 68 \\
75714 & 94003 & ash & 3 & 727 & 234 & 346 & 86 & 141 & 166 & 64 & $\mathrm{dl}$ & 480 & 392 & 328 & 152 & $\mathrm{dl}$ & 6 & 1229 & 63 \\
75715 & 94005 & ash & 4 & 692 & 226 & 357 & 76 & 131 & 161 & 70 & $\mathrm{dl}$ & 487 & 437 & 324 & 160 & $\mathrm{dl}$ & 8 & 1281 & 61 \\
75716 & 94007 & ash & 5 & 719 & 237 & 325 & 86 & 138 & 170 & 63 & $\mathrm{dl}$ & 486 & 368 & 318 & 149 & $\mathrm{dl}$ & 6 & 1198 & 62 \\
75717 & 94009 & ash & comp. & 716 & 231 & 318 & 83 & 140 & 127 & 48 & $\mathrm{dl}$ & 481 & 419 & 344 & 177 & $\mathrm{dl}$ & 8 & 1223 & 60
\end{tabular}

\begin{tabular}{|c|c|c|c|c|c|c|c|c|c|c|c|c|c|c|c|c|c|c|c|}
\hline MANumber & SampleID & material & key & $\mathrm{Sc}$ & $\mathrm{Y}$ & $\mathrm{La}$ & $\mathrm{Ce}$ & $\operatorname{Pr}$ & $\mathrm{Nd}$ & $\mathrm{Sm}$ & $\mathrm{Eu}$ & $\mathrm{Gd}$ & $\mathrm{Tb}$ & Dy & Ho & $\mathrm{Er}$ & $\mathrm{Tm}$ & $\mathrm{Yb}$ & $\mathrm{Lu}$ \\
\hline 75706 & 93988 & coal & 1 & 40 & 41 & 94 & 217 & 24 & 241 & 15 & 3 & 19 & 7 & 11 & $\mathrm{dl}$ & 14 & $\mathrm{dl}$ & 7 & 2 \\
\hline 75707 & 94000 & coal & 2 & 40 & 36 & 84 & 191 & 20 & 225 & 14 & 3 & 16 & 6 & 10 & $\mathrm{dl}$ & 12 & $\mathrm{dl}$ & 7 & 1 \\
\hline 75708 & 94002 & coal & 3 & 41 & 41 & 93 & 210 & 23 & 242 & 15 & 3 & 18 & 6 & 11 & $\mathrm{dl}$ & 13 & $\mathrm{dl}$ & 7 & 2 \\
\hline 75709 & 94004 & coal & 4 & 35 & 32 & 79 & 181 & 20 & 234 & 13 & 3 & 16 & 5 & 8 & $\mathrm{dl}$ & 12 & $\mathrm{dl}$ & 6 & 1 \\
\hline 75710 & 94006 & coal & 5 & 34 & 29 & 74 & 176 & 19 & 232 & 13 & 3 & 15 & 6 & 9 & $\mathrm{dl}$ & 12 & $\mathrm{dl}$ & 6 & 1 \\
\hline 75711 & 94008 & coal & comp. & 35 & 30 & 75 & 176 & 18 & 215 & 12 & 3 & 15 & 5 & 9 & $\mathrm{dl}$ & 12 & $\mathrm{dl}$ & 6 & 1 \\
\hline 75712 & 93999 & ash & 1 & 45 & 48 & 98 & 212 & 23 & 250 & 15 & 3 & 19 & 6 & 12 & $\mathrm{dl}$ & 14 & $\mathrm{dl}$ & 8 & 2 \\
\hline 75713 & 94001 & ash & 2 & 40 & 48 & 94 & 207 & 23 & 253 & 15 & 3 & 19 & 6 & 12 & $\mathrm{dl}$ & 15 & $\mathrm{dl}$ & 8 & 2 \\
\hline 75714 & 94003 & ash & 3 & 44 & 48 & 103 & 221 & 26 & 264 & 16 & 4 & 19 & 6 & 12 & $\mathrm{dl}$ & 14 & $\mathrm{dl}$ & 8 & 2 \\
\hline 75715 & 94005 & ash & 4 & 41 & 41 & 93 & 206 & 24 & 235 & 14 & 3 & 19 & 6 & 11 & $\mathrm{dl}$ & 13 & $\mathrm{dl}$ & 7 & $\mathrm{dl}$ \\
\hline 75716 & 94007 & ash & 5 & 45 & 48 & 103 & 219 & 25 & 259 & 16 & 3 & 20 & 7 & 13 & $\mathrm{dl}$ & 14 & $\mathrm{dl}$ & 8 & 2 \\
\hline 75717 & 94009 & ash & comp. & 43 & 26 & 99 & 214 & 23 & 257 & 15 & 3 & 19 & 7 & 12 & $\mathrm{dl}$ & 14 & $\mathrm{dl}$ & 9 & 2 \\
\hline MANumber & SampleID & material & key & & & $\mathrm{La}$ & $\mathrm{Ce}$ & $\operatorname{Pr}$ & $\mathrm{Nd}$ & $\mathrm{Sm}$ & $\mathrm{Eu}$ & $\mathrm{Gd}$ & $\mathrm{Tb}$ & Dy & Ho & $\mathrm{Er}$ & $\mathrm{Tm}$ & $\mathrm{Yb}$ & $\mathrm{Lu}$ \\
\hline$*$ & & & & & & 30 & 64 & 7.1 & 26 & 4.5 & 0.88 & 3.8 & 0.64 & 3.5 & 0.8 & 2.3 & 0.33 & 2.2 & 0.32 \\
\hline 75706 & 93988 & coal & 1 & & & 3.13 & 3.39 & 3.38 & 9.27 & 3.33 & 3.41 & 5.00 & 11.67 & 3.14 & & 6.09 & & 3.18 & 6.67 \\
\hline 75707 & 94000 & coal & 2 & & & 2.80 & 2.98 & 2.82 & 8.65 & 3.11 & 3.41 & 4.21 & 10.00 & 2.86 & & 5.22 & & 3.18 & 3.33 \\
\hline 75708 & 94002 & coal & 3 & & & 3.10 & 3.28 & 3.24 & 9.31 & 3.33 & 3.41 & 4.74 & 10.00 & 3.14 & & 5.65 & & 3.18 & 6.67 \\
\hline 75709 & 94004 & coal & 4 & & & 2.63 & 2.83 & 2.82 & 9.00 & 2.89 & 3.41 & 4.21 & 8.33 & 2.29 & & 5.22 & & 2.73 & 3.33 \\
\hline 75710 & 94006 & coal & 5 & & & 2.47 & 2.75 & 2.68 & 8.92 & 2.89 & 3.41 & 3.95 & 10.00 & 2.57 & & 5.22 & & 2.73 & 3.33 \\
\hline 75711 & 94008 & coal & comp. & & & 2.50 & 2.75 & 2.54 & 8.27 & 2.67 & 3.41 & 3.95 & 8.33 & 2.57 & & 5.22 & & 2.73 & 3.33 \\
\hline 75712 & 93999 & ash & 1 & & & 3.27 & 3.31 & 3.24 & 9.62 & 3.33 & 3.41 & 5.00 & 10.00 & 3.43 & & 6.09 & & 3.64 & 6.67 \\
\hline 75713 & 94001 & ash & 2 & & & 3.13 & 3.23 & 3.24 & 9.73 & 3.33 & 3.41 & 5.00 & 10.00 & 3.43 & & 6.52 & & 3.64 & 6.67 \\
\hline 75714 & 94003 & ash & 3 & & & 3.43 & 3.45 & 3.66 & 10.15 & 3.56 & 4.55 & 5.00 & 10.00 & 3.43 & & 6.09 & & 3.64 & 6.67 \\
\hline 75715 & 94005 & ash & 4 & & & 3.10 & 3.22 & 3.38 & 9.04 & 3.11 & 3.41 & 5.00 & 10.00 & 3.14 & & 5.65 & & 3.18 & \\
\hline 75716 & 94007 & ash & 5 & & & 3.43 & 3.42 & 3.52 & 9.96 & 3.56 & 3.41 & 5.26 & 11.67 & 3.71 & & 6.09 & & 3.64 & 6.67 \\
\hline 75717 & 94009 & ash & comp. & & & 3.30 & 3.34 & 3.24 & 9.88 & 3.33 & 3.41 & 5.00 & 11.67 & 3.43 & & 6.09 & & 4.09 & 6.67 \\
\hline
\end{tabular}

* correction for concentration in upper continental crust (after ref. 14) 


\section{Table 2 part 3}

\begin{tabular}{ccccccccc}
\hline MANumber & SampleID & REY & LREE & HREE & LREE/HREE & EuN/EuN* & CeN/CeN* & GdN/GdN* \\
\hline 75706 & 93988 & 695 & 591 & 63 & 9.38 & 0.24 & 3.68 & 1.97 \\
75707 & 94000 & 625 & 534 & 55 & 9.71 & 0.26 & 3.67 & 1.85 \\
75708 & 94002 & 684 & 583 & 60 & 9.72 & 0.25 & 3.62 & 2.01 \\
75709 & 94004 & 610 & 527 & 51 & 10.33 & 0.29 & 3.66 & 2.09 \\
75710 & 94006 & 595 & 514 & 52 & 9.88 & 0.28 & 3.78 & 1.81 \\
75711 & 94008 & 577 & 496 & 51 & 9.73 & 0.31 & 3.78 & 2.05 \\
75712 & 93999 & 710 & 598 & 64 & 9.34 & 0.25 & 3.50 & 2.12 \\
75713 & 94001 & 705 & 592 & 65 & 9.11 & 0.25 & 3.54 & 2.12 \\
75714 & 94003 & 743 & 630 & 65 & 9.69 & 0.31 & 3.43 & 2.04 \\
75715 & 94005 & 672 & 572 & 59 & 9.69 & 0.26 & 3.52 & 2.20 \\
75716 & 94007 & 737 & 622 & 67 & 9.28 & 0.23 & 3.42 & 2.01 \\
75717 & 94009 & 700 & 608 & 66 & 9.21 & 0.24 & 3.51 & 1.97
\end{tabular}

* correction for concentration in upper continental crust (after ref. 14) 


\begin{tabular}{|c|c|c|c|c|c|c|c|c|c|c|c|c|}
\hline sample & 93998 & & 94000 & & 94002 & & 94004 & & 94006 & & 94008 & \\
\hline key & 1 & & 2 & & 3 & & 4 & & 5 & & comp. & \\
\hline telinite & 11.0 & 12.2 & 19.6 & 20.5 & 9.6 & 10.2 & 7.4 & 7.8 & 9.9 & 10.5 & 15.6 & 17.0 \\
\hline collotelinite & 58.2 & 64.4 & 55.7 & 58.1 & 51.8 & 54.5 & 61.9 & 65.1 & 50.0 & 53.3 & 55.5 & 60.5 \\
\hline total telovitrinite & 69.2 & 76.6 & 75.3 & 78.5 & 61.4 & 64.6 & 69.3 & 73.0 & 59.9 & 63.8 & 71.1 & 77.5 \\
\hline vitrodetrinite & 4.1 & 4.6 & 5.7 & 5.9 & 11.1 & 11.7 & 6.2 & 6.5 & 8.2 & 8.7 & 5.9 & 6.4 \\
\hline collodetrinite & 0.0 & 0.0 & 0.0 & 0.0 & 0.0 & 0.0 & 0.0 & 0.0 & 0.0 & 0.0 & 0.0 & 0.0 \\
\hline total detrovitrinite & 4.1 & 4.6 & 5.7 & 5.9 & 11.1 & 11.7 & 6.2 & 6.5 & 8.2 & 8.7 & 5.9 & 6.4 \\
\hline corpogelinite & 0.8 & 0.9 & 0.6 & 0.7 & 0.6 & 0.6 & 0.3 & 0.3 & 0.7 & 0.7 & 0.6 & 0.6 \\
\hline gelinite & 0.0 & 0.0 & 0.3 & 0.3 & 0.0 & 0.0 & 0.0 & 0.0 & 0.0 & 0.0 & 0.0 & 0.0 \\
\hline total gelovitrinite & 0.8 & 0.9 & 0.9 & 1.0 & 0.6 & 0.6 & 0.3 & 0.3 & 0.7 & 0.7 & 0.6 & 0.6 \\
\hline total vitrinite & 74.2 & 82.1 & 82.0 & 85.5 & 73.1 & 76.9 & 75.9 & 79.8 & 68.7 & 73.2 & 77.6 & 84.6 \\
\hline fusinite & 15.1 & 16.7 & 13.0 & 13.5 & 20.2 & 21.2 & 18.0 & 18.9 & 24.1 & 25.7 & 13.0 & 14.1 \\
\hline semifusinite & 0.8 & 0.9 & 0.3 & 0.3 & 0.6 & 0.6 & 0.6 & 0.7 & 0.7 & 0.7 & 0.3 & 0.3 \\
\hline micrinite & 0.3 & 0.3 & 0.0 & 0.0 & 0.0 & 0.0 & 0.0 & 0.0 & 0.0 & 0.0 & 0.0 & 0.0 \\
\hline macrinite & 0.0 & 0.0 & 0.0 & 0.0 & 0.0 & 0.0 & 0.0 & 0.0 & 0.0 & 0.0 & 0.0 & 0.0 \\
\hline secretinite & 0.0 & 0.0 & 0.6 & 0.7 & 1.2 & 1.2 & 0.6 & 0.7 & 0.3 & 0.4 & 0.6 & 0.6 \\
\hline funginite & 0.0 & 0.0 & 0.0 & 0.0 & 0.0 & 0.0 & 0.0 & 0.0 & 0.0 & 0.0 & 0.0 & 0.0 \\
\hline inertodetrinite & 0.0 & 0.0 & 0.0 & 0.0 & 0.0 & 0.0 & 0.0 & 0.0 & 0.0 & 0.0 & 0.0 & 0.0 \\
\hline total inertinite & 16.2 & 17.9 & 13.9 & 14.5 & 21.9 & 23.1 & 19.2 & 20.2 & 25.2 & 26.8 & 13.9 & 15.1 \\
\hline sporinite & 0.0 & 0.0 & 0.0 & 0.0 & 0.0 & 0.0 & 0.0 & 0.0 & 0.0 & 0.0 & 0.3 & 0.3 \\
\hline cutinite & 0.0 & 0.0 & 0.0 & 0.0 & 0.0 & 0.0 & 0.0 & 0.0 & 0.0 & 0.0 & 0.0 & 0.0 \\
\hline resinite & 0.0 & 0.0 & 0.0 & 0.0 & 0.0 & 0.0 & 0.0 & 0.0 & 0.0 & 0.0 & 0.0 & 0.0 \\
\hline alginite & 0.0 & 0.0 & 0.0 & 0.0 & 0.0 & 0.0 & 0.0 & 0.0 & 0.0 & 0.0 & 0.0 & 0.0 \\
\hline liptodetrinite & 0.0 & 0.0 & 0.0 & 0.0 & 0.0 & 0.0 & 0.0 & 0.0 & 0.0 & 0.0 & 0.0 & 0.0 \\
\hline suberinite & 0.0 & 0.0 & 0.0 & 0.0 & 0.0 & 0.0 & 0.0 & 0.0 & 0.0 & 0.0 & 0.0 & 0.0 \\
\hline exsudatinite & 0.0 & 0.0 & 0.0 & 0.0 & 0.0 & 0.0 & 0.0 & 0.0 & 0.0 & 0.0 & 0.0 & 0.0 \\
\hline total liptinite & 0.0 & 0.0 & 0.0 & 0.0 & 0.0 & 0.0 & 0.0 & 0.0 & 0.0 & 0.0 & 0.3 & 0.3 \\
\hline silicate & 9.3 & & 3.8 & & 5.0 & & 4.6 & & 5.8 & & 8.0 & \\
\hline sulfide & 0.3 & & 0.3 & & 0.0 & & 0.0 & & 0.0 & & 0.0 & \\
\hline carbonate & 0.0 & & 0.0 & & 0.0 & & 0.0 & & 0.3 & & 0.3 & \\
\hline other & 0.0 & & 0.0 & & 0.0 & & 0.3 & & 0.0 & & 0.0 & \\
\hline total mineral & 9.6 & & 4.1 & & 5.0 & & 5.0 & & 6.1 & & 8.3 & \\
\hline Rmax & 5.65 & & 5.78 & & 5.31 & & 5.05 & & 5.26 & & 5.35 & \\
\hline st dev & 0.47 & & 0.40 & & 0.62 & & 0.43 & & 0.42 & & 0.63 & \\
\hline Rrandom & 4.73 & & 4.92 & & 4.63 & & 4.40 & & 4.50 & & 4.67 & \\
\hline st dev & 0.41 & & 0.45 & & 0.52 & & 0.42 & & 0.43 & & 0.65 & \\
\hline
\end{tabular}




$\begin{array}{lrrrrrr}\text { sample } & 93999 & 94001 & 94003 & 94005 & 94007 & 94009 \\ \text { key } & 1 & 2 & 3 & 4 & 5 & \text { comp. } \\ \text { glass } & 61.1 & 64.9 & 70.8 & 67.2 & 71.6 & 63.1 \\ \text { mullite } & 2.5 & 2.6 & 0.3 & 0.3 & 0.0 & 0.3 \\ \text { spinel } & \mathrm{t} & 1.2 & 1.8 & 0.3 & 2.5 & 1.7 \\ \text { quartz } & 0.7 & 0.0 & 0.0 & 0.0 & 0.0 & 0.0 \\ \text { sulfide } & 0.0 & 0.0 & 0.6 & 0.0 & 0.0 & 0.0 \\ \text { sulfate } & 1.8 & 0.9 & 0.6 & 0.0 & 0.3 & 0.0 \\ \text { rock fragment } & 2.5 & 2.6 & 2.4 & 0.3 & 0.3 & 0.9 \\ \text { isotropic coke } & 0.4 & 0.6 & 0.0 & 0.0 & 0.0 & 0.3 \\ \text { anisotropic coke } & 0.0 & 0.0 & 0.0 & 0.3 & 0.0 & 0.0 \\ \text { inertinite } & 0.7 & 0.0 & 0.3 & 0.0 & 0.0 & 0.0 \\ \text { unburned coal } & 30.5 & 27.2 & 22.8 & 31.5 & 25.3 & 33.8\end{array}$

